\title{
An Insightful Molecular Analysis Reveals Foreign Honeybees Among Algerian Honeybee Populations (Apis mellifera L.)
}

Mohamed Achou ${ }^{1}$, WahidaLoucif-Ayad ${ }^{1,2}$, Hélène Legout ${ }^{3}$, Hayan Hmidan ${ }^{4}$, Mohamed Alburaki ${ }^{*}$ and Lionel Garnery ${ }^{3,6}$

${ }^{1}$ Laboratoire de Biologie Animale Appliquée, UniversitéBadji-MokhtarB.P.13, Sidi-Amar, Annaba, Algéria

${ }^{2}$ Faculté de Médecine, Route de Zaâfrania, B.P 205, Université Badji-Mokhtar, Annaba, Algéria

${ }^{3}$ Laboratoire Evolution, Génomeset Spéciation, CNRS, Bât13, Avenue de la Terrasse, 91198, Gif-sur-Yvette, France

${ }^{4}$ Université du Québec à Montréal (UQAM), Département de géographie, Case Postale 8888, Succursalecentre-ville Montréal, Québec, H3C 3P8, Canada

${ }^{5}$ The University of Tennessee, Entomology and Plant Pathology Department, West TN Research and Education Center, 605 Airways Blvd., Jackson, TN, 38301, USA

${ }^{6}$ Université de Versailles, Saint Quentin en Yvelines, 45 Avenue des Etats-Unis, 78 Versailles

\begin{abstract}
This study assessed the genetic diversity of honeybees (Apis mellifera) in Algeria, in North Africa, using the molecular marker mtDNA COI-COII (Cytochrome Oxidase I and II). In total, five hundred eighty-two honeybee workers were sampled from 22 regions of the country. A PCR-RFLP (Polymerase Chain Reaction Restriction Fragment Length Polymorphism) analysis of the mtDNA samples distinguished the honeybee evolutionary lineages and mtDNA haplotypes from each region. Our data revealed the presence of three different honeybee lineages among the studied populations, comprising the African (A), North Mediterranean (C) and West Mediterranean (M) lineages. Eight different mtDNA haplotypes were recorded at various frequencies (A1, A2, A8, A9, A10, A13, C7 and M4). For the first time, our results identified a low genetic introgression (3.1\%) of non-local mtDNA haplotypes (C7 and M4) among the local Algerian honeybees, most likely due to the import of foreign honeybees. Notably, the southern Algerian honeybee populations had lower haplotype diversity than the northern populations. Overall, the local North African honeybee subspecies A. $m$. intermissa and/or $A$. m.sahariensis seem to be remarkably dominant across northern Algeria.
\end{abstract}

Keywords: Apis mellifera intermissa; mtDNA marker; Haplotype diversity; Introgression; Evolutionary lineage; Algerian honeybee populations

\section{Introduction}

Subspecies of the honeybee, Apis mellifera L., were first classified according to their morphological and behavioral traits along with their geographical distributions [1,2]. Morphometrical analyses conducted on large datasets have established four different evolutionary lineages of honeybees: "M" in Northern and Western Europe, "A" in Africa, "C" in Southeastern Europe, and "O" in Western Asia [1-3].

Subsequent studies based on variation in mitochondrial DNA largely confirmed Ruttner's phylogeographic structure of A. mellifera [4-11]. The different molecular markers that have been used to study the genetic diversity of $A$. mellifera have provided a more precise tool than classical morphometrical studies, enabling the transition to molecular analyses. Moreover, molecular markers have facilitated more robust assessments of honeybee diversity, such as the reclassification of North African subspecies (A. m. intermissa and A. m. sahariensis) into the African branch instead of the West European branch [8], and the delimitation of different lineages in the Middle East [12-14].

In the last two decades of honeybee genetic analysis and conservation, mtDNA and microsatellite markers have been used the most commonly [15-20]. The maternal inheritance of MtDNA in honeybees [21] has made it a suitable and popular molecular marker for tracing the genetic origin and structure of honeybees [9,22-25]. Similar to the classical morphometrical analyzes, the mtDNA variation in honeybees revealed several main evolutionary lineages $[4,5,26]$. However, importation of foreign queens in a local honeybee genetic pool is hard to identify using classical morphometrical analyzes and requires more powerful molecular markers such as the mtDNA. Based on findings with these molecular markers and previous morphometrical analyzes, 29 different honeybee subspecies have been identified around the world and grouped into four evolutionary lineages [1,2,27-34].
The honeybee subspecies that are native to North Africa belong to the African lineage A, [2,35-37]. In Algeria, two different honeybee subspecies have been recorded: A. mellifera intermissa and A. mellifera sahariensis [38]. The intermissa subspecies is found in North Africa (Tunisia, Algeria and Morocco) and spreads into the northern Sahara, from Libya to the Moroccan Coast of the Atlantic Ocean [1,2]. The sahariensis distribution extends along the Djebel Amour and AinSefra in Algeria, to various oases from Figuig to Ouarzazate in Morocco [3840]. However, in the oasis of the eastern Sahara, only A. m. intermissa is present [40].

The morphometrics of these two North African subspecies have been studied in Tunisia [41], Morocco [42] and Algeria [43,44]. The genetic diversity of the Northern African honeybee populations has been explored previously, though only on a relatively small scale [3537,45,46]. These previous studies revealed an African origin of the North African populations and classified them within the African honeybee lineage A.

During the last few years, beekeeping activity in Algeria has seen remarkable growth and development across the country. Although the importation and exportation of honeybees is highly regulated by Algerian law, some foreign queens are still brought into the country

${ }^{*}$ Corresponding author: Mohamed Alburaki, The University of Tennessee Entomology and Plant Pathology Department, West TN Research and Education Center, 605 Airways Blvd, Jackson TN 38301, USA, Tel: +1 (731) 425-4759; Fax: +1 (731) 425-4720; E-mail: malburak@utk.edu

Received December 05, 2014; Accepted January 30, 2015; Published February 07, 2015

Citation: Achou M, Loucif-Ayad W, Legout H, Hmidan H, Alburaki M, et al.(2015) An Insightful Molecular Analysis Reveals Foreign Honeybees Among Algerian Honeybee Populations (Apis mellifera L.) J Data Mining Genomics Proteomics 6: 166. doi:10.4172/2153-0602.1000166

Copyright: ( 2015 Achou M, et al. This is an open-access article distributed unde the terms of the Creative Commons Attribution License, which permits unrestricted use, distribution, and reproduction in any medium, provided the original author and source are credited. 
due to the belief that they might provide better honey production and have superior disease resistance than local honeybees.

The objective of this study was to measure the genetic diversity of Algerian honeybee populations based on a large number of samples taken from 22 regions of the country. We used the COI-COII mtDNA marker (widely used in studies of honeybees) to identify the evolutionary lineages along with various haplotypes in our samples. Being based on an unprecedented number of samples from Algeria, this work characterizes the mitochondrial genetic structure of the country's honeybee populations, and presents a current estimation of the introgression levels among populations and the resulting impact on local Algerianhoneybee diversity.

\section{Materials and Methods}

\section{Honeybee sampling}

In total, 582 honeybee colonies were sampled from 22 regions across northern Algeria. The geographical location and number of individuals sampled from each region are shown in Figure 1 and Table 1. These regions represent almost half of those in Algeria and contain the most significant beekeeping activity in the country. One worker bee was sampled per colony, preserved individually in absolute ethanol, and kept at $-20^{\circ} \mathrm{C}$ until analysis $[6,26,33]$.

\section{DNA extraction}

DNA was obtained from the homogenized head and thorax of each bee using a standard phenol-chloroform extraction method [47], with some modifications as described previously [6]. The total DNA extracted from each honeybee sample was subsequently preserved at $-20^{\circ} \mathrm{C}$ for further genetic analysis.

\section{Mitochondrial DNA analysis}

We amplified the mtDNA COI-COII intergenic region located between the tRNA ${ }^{\text {Leu }}$ gene and the second subunit of the cytochrome oxidase gene II (COII) using the primer pair E2: (5'-GGC AGA ATA AGT GCA TTG-3') and H2: (5'-CAA TAT CAT TGA TGA CC-3') $[6,7,9,13,33,36]$.

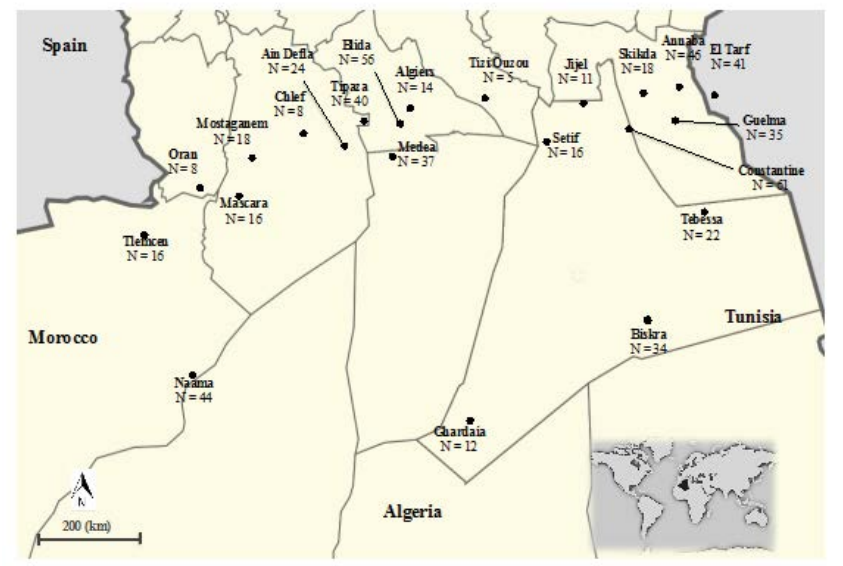

Figure 1. Geographical locations of the 22 sampled regions on the map of Algeria. $\mathrm{N}$ is the number of honeybee colonies studied in each region. Bees collected from different colonies in each region were treated as one combined sample representing the honeybee population of that region. GPS coordinates for each region are given in Table 1.
PCR amplification of the COI-COII intergenic region was performed in a volume of $25 \mu \mathrm{L}$ that contained $0.8 \mu \mathrm{M}$ of each primer, $0.2 \mathrm{mM}$ of PCR nucleotide mix (Boehringer Mannheim), $1.5 \mathrm{mM}$ $\mathrm{MgCl}_{2}$ (Promega), 1 X Reaction Buffer (Promega), 1 U Taq Polymerase (Promega) and $1 \mu \mathrm{L}$ of template. The amplification cycle consisted of an initial denaturation step of $2 \mathrm{~min}$ at $92^{\circ} \mathrm{C}$, followed by 35 cycles of 30 $\mathrm{s}$ at $92^{\circ} \mathrm{C}, 30 \mathrm{~s}$ at $47^{\circ} \mathrm{C}$ and $2 \mathrm{~min}$ at $63^{\circ} \mathrm{C}$, followed by a final extension step of $10 \mathrm{~min}$ at $63^{\circ} \mathrm{C}$.

\section{Honeybee evolutionary lineage}

In order to identify the evolutionary lineage of each individual, $2 \mu \mathrm{L}$ of each PCR product was loaded into $1.4 \%$ agarose gel and electrophoresed along with the MIII marker (Roche Diagnostics $\mathrm{GmbH}$ ). The gel was then stained for $10 \mathrm{~min}$ with ethidium bromide (EtBrat $0.5 \mu \mathrm{g} / \mathrm{mL}$ ) and finally observed under UV illumination. The length of the amplified mtDNA COI-COII intergenic region was measured for each sample, using the MIII marker $[6,26]$.

\section{Haplotype identification}

The remaining $23 \mu \mathrm{L}$ volume of each PCR product was digested with the restriction enzyme $\operatorname{DraI}$ at $37^{\circ} \mathrm{C}$ for 48 hours. Then $6 \mu \mathrm{L}$ of the restricted DNA along with haplotypes that had been previously identified from various lineages were loaded and electrophoresed on $7.5 \%$ and $10 \%$ acrylamide gels, run at $150 \mathrm{~V}$ for 3 hours. DNA patterns of each sample were observed under UV illumination following the addition of $0.5 \mu \mathrm{g} / \mathrm{mL}$ ethidium bromide.

\section{Statistical analysis}

Honeybees sampled from each region were treated as one population representing that region (Tables 1 and 2). The haplotype diversity of each such population was calculated according to [48]. Estimated values of haplotype introgression were calculated based on the total number of haplotypes in each population, after excluding the non-local haplotypes. Before analysis, the data for each measured variable were tested for normality with the Shapiro-Wilk test. Pairwise t-tests were performed to assess any differences between the various haplotypes found in the studied regions, and between local and imported haplotypes. Statistical differences were considered as significant when p-value is below 0.05 (confidence interval of 95\%). All statistical analyses were conducted in the R environment [49]. The different representations of the haplotype geographical mapping were performed using ArcGIS ${ }^{\infty}$ software (http://www.esri.com/software/ arcgis) by Esri under license.

\section{Results}

Based on the COI-COII mtDNA marker, three different evolutionary lineages were detected among our samples: African (A), West Mediterranean (M) and North Mediterranean (C) lineages (Table 2). The COI-COII intergenicmt DNA region had five different lengths or patterns in the studied populations; they were $\mathrm{Q}, \mathrm{PQQ}, \mathrm{P}_{0} \mathrm{Q}$, $P_{0} Q Q$ and $P_{0} Q Q Q$ (Table 2). The Q fragment characterized the North Mediterranean lineage $(\mathrm{C})$, while the $\mathrm{P}(54 \mathrm{bp})$ and $\mathrm{P}_{0}(67 \mathrm{bp})$ sequences characterized honeybee subspecies of the West (M) and African (A) lineages respectively [26].

\section{MtDNA haplotype}

In total, eight different mtDNA haplotypes were identified at different frequencies among our 582 samples (Table 2). These haplotypes belonged to three evolutionary lineages: the African lineage A (A1, A2, A8, A9, A10, A13), West Mediterranean lineage M (M4), 


\begin{tabular}{|c|c|c|c|}
\hline $\begin{array}{c}\text { Honeybee population / Algerian } \\
\text { Region }\end{array}$ & GPS Coordinates & Altitude & $\mathbf{N}^{\circ}$ of worker bees sampled \\
\hline 1. Ain Defla & $36^{\circ} 04^{\prime} \mathrm{N} 1^{\circ} 59^{\prime} \mathrm{E}$ & $269 \mathrm{~m}$ & 24 \\
\hline 2. Algiers & $36^{\circ} 45^{\prime} \mathrm{N} 3^{\circ} 31^{\prime} \mathrm{E}$ & $144 \mathrm{~m}$ & 14 \\
\hline 3. Annaba & $36^{\circ} 53^{\prime} \mathrm{N} 7^{\circ} 45^{\prime} \mathrm{E}$ & $61 \mathrm{~m}$ & 46 \\
\hline 4. Biskra & $34^{\circ} 51^{\prime} \mathrm{N}^{\circ} 44^{\prime} \mathrm{E}$ & $119 \mathrm{~m}$ & 34 \\
\hline 5. Blida & $36^{\circ} 31^{\prime} \mathrm{N} 2^{\circ} 58^{\prime} \mathrm{E}$ & $139 \mathrm{~m}$ & 56 \\
\hline 6. Chlef & $36^{\circ} 10^{\prime} \mathrm{N} 1^{\circ} 20^{\prime} \mathrm{E}$ & $100 \mathrm{~m}$ & 8 \\
\hline 7. Constantine & $36^{\circ} 21^{\prime} \mathrm{N} 6^{\circ} 36^{\prime} \mathrm{E}$ & $573 \mathrm{~m}$ & 61 \\
\hline 8. El Tarf & $36^{\circ} 46^{\prime} \mathrm{N} 8^{\circ} 13^{\prime} \mathrm{E}$ & $24 \mathrm{~m}$ & 41 \\
\hline 9. Ghardaia & $32^{\circ} 36^{\prime} \mathrm{N} 3^{\circ} 44^{\prime} \mathrm{E}$ & $496 \mathrm{~m}$ & 12 \\
\hline 10. Guelma & $36^{\circ} 27^{\prime} \mathrm{N} 7^{\circ} 36^{\prime} \mathrm{E}$ & $306 \mathrm{~m}$ & 35 \\
\hline 11. Jijel & $36^{\circ} 48^{\prime} \mathrm{N} 5^{\circ} 45^{\prime} \mathrm{E}$ & $23 \mathrm{~m}$ & 12 \\
\hline 12. Mascara & $35^{\circ} 23^{\prime} \mathrm{N} 0^{\circ} 08^{\prime} \mathrm{E}$ & $651 \mathrm{~m}$ & 16 \\
\hline 13. Medea & $36^{\circ} 16^{\prime} \mathrm{N} 2^{\circ} 45^{\prime} \mathrm{E}$ & $782 \mathrm{~m}$ & 37 \\
\hline 14. Mostaganem & $35^{\circ} 55^{\prime} \mathrm{N} 0^{\circ} 05^{\prime} \mathrm{E}$ & $79 \mathrm{~m}$ & 22 \\
\hline 15. Naama & $32^{\circ} 45^{\prime} \mathrm{N} 0^{\circ} 34^{\prime} \mathrm{W}$ & $1119 \mathrm{~m}$ & 44 \\
\hline 16. Oran & $35^{\circ} 51^{\prime} \mathrm{N} 0^{\circ} 18^{\prime} \mathrm{W}$ & $114 \mathrm{~m}$ & 8 \\
\hline 17. Setif & $36^{\circ} 11^{\prime} \mathrm{N} 5^{\circ} 24^{\prime} \mathrm{E}$ & $1060 \mathrm{~m}$ & 16 \\
\hline 18. Skikda & $36^{\circ} 51^{\prime} \mathrm{N} 8^{\circ} 13^{\prime} \mathrm{E}$ & $27 \mathrm{~m}$ & 18 \\
\hline 19. Tebessa & $35^{\circ} 23^{\prime} \mathrm{N} 8^{\circ} 65^{\prime} \mathrm{E}$ & $834 \mathrm{~m}$ & 22 \\
\hline 20. Tipaza & $36^{\circ} 36^{\prime} \mathrm{N} 2^{\circ} 23^{\prime} \mathrm{E}$ & $270 \mathrm{~m}$ & 40 \\
\hline 21. Tizi Ouzou & $36^{\circ} 43^{\prime} \mathrm{N} 4^{\circ} 30^{\prime} \mathrm{E}$ & $277 \mathrm{~m}$ & 5 \\
\hline 22. Tlemcen & $34^{\circ} 52^{\prime} \mathrm{N} 1^{\circ} 18^{\prime} \mathrm{W}$ & $742 \mathrm{~m}$ & 16 \\
\hline Total & & & 582 \\
\hline
\end{tabular}

Table 1. Location and number of honeybees sampled (one worker bee/colony) for each of the 22 regions studied in Algeria.

and North Mediterranean lineage C (C7). Evolutionary lineage A was significantly dominant $(P<0.001)$ compared to both the $\mathrm{M}$ and $\mathrm{C}$ lineages (Figure 2). The same statistical pattern was observed after grouping of samples from the $\mathrm{M}$ and $\mathrm{C}$ lineages and considering them as a non-local honeybee group $(\mathrm{T}=-7.227, P<0.001)$. No significant differences were found between samples from the $M$ and $C$ lineages ( $\mathrm{T}=1.22, P=0.23$; Figure 2 and Table 3 ).

\section{Haplotype diversity}

The three most dominant haplotypes in Algerian honeybee populations were A9 (206 colony, 35.9\%) followed by A8 (172 colony, 29.55\%) and A1 (171 colony, 29.38\%; Table 2 and Figure 3). Other haplotypes were recorded punctually in some specific regions. For example, haplotypes A2 and A13 were only found in the Naama region, one haplotype (A10) was found only in Algiers, while haplotype C7 was recorded in only two regions (El Tarf and Tebessa), close to the Tunisian border (Table 2, Figures 1 and 3). Based on our sampling, the highest haplotype diversity was recorded in the Algiers and Mostaganem regions (0.758) with an estimated haplotype introgression of 0 and 38.8 respectively (Table 2). Ghardaia had no haplotype diversity, as only one haplotype (A8) was found in the population (Table 2 and Figure 3). Across the Algerian honeybee dataset, haplotype diversity of populations was 0.701 , with $3.1 \%$ foreign or non-local honeybee introgression (Table2).

Throughout the studied regions, there were highly significant differences between the number of the African A1 and A2 haplotypes (Paired t-test, $t=4.215, P<0.001$; Table 3 ). There was no significant difference in the number of the two non-local haplotypes, M4 vs C7 $(\mathrm{t}=1.226, P=0.23)$, or in the haplotype pairs $\mathrm{A} 1$ vs $\mathrm{A} 8, \mathrm{~A} 1$ vs $\mathrm{A} 9$ and $\mathrm{A} 8$ vs A9 (Table 3 and Figure 2).

\section{Discussion}

Our study was based mainly on the COI-COII mtDNA marker, in order to characterize the genetic variability of the Algerian honeybee populations on a large geographical scale and honeybee samples.

The 22 regions that we sampled are concentrated in the northern parts of Algeria, as the southern parts of the country are mostly desert environments that do not support commercial beekeeping (Figure 1). Our results revealed five different COI-COII mtDNA patterns across the study area ( $\mathrm{Q}, \mathrm{PQQ}, \mathrm{P}_{0} \mathrm{Q}, \mathrm{P}_{0} \mathrm{QQ}$ and $\mathrm{P}_{0} \mathrm{QQQ}$; Table 2). Interestingly, the first two patterns ( $Q$ and $P Q Q$ ) do not belong to the African lineage $A$ and they are in fact unexpected among North African honeybee populations $[9,13]$. Indeed, samples that contained these two patterns (Q and PQQ) revealed two corresponding imported haplotypes (C7 and M4) that belong to the North and West Mediterranean lineages, respectively (Table 2). To the best of our knowledge, this is the first time that imported haplotypes have been documented in Algerian honeybee populations. All other haplotypes that we identified (A1, A2, A8, A9, A10, A13) belong to the local African lineage, A [9,35,37]. This finding confirms a weak mtDNA introgression within local honeybee populations, estimated at $3.1 \%$, most likely due to foreign queen and/ or honeybee importations (Table2). These results are highly consistent with those based on prior microsatellite analysis of the same honeybee samples [51]; that earlier paper reported weak nuclear introgressions from the $\mathrm{C}$ and $\mathrm{M}$ lineages. Haplotype $\mathrm{C7}$, a rare haplotype found in Tunisia [52], Cyprus and Turkish populations, was recorded in only two regions that were close to the Tunisian border (El Tarf and Tebessa), from where it has probably been imported (Figure 1,3 and Table 2). However, haplotype M4 is a well-known haplotype that is found frequently in France, especially in the western and middle parts of the country $[53,54]$. Despite the low number of importations that was detected, Algerian local honeybees maintained a significantly higher presence $(96.9 \%)$ compared to non-local honeybees $(\mathrm{t}=-7.227$, $P<0.001$; Figure 2 and Table 3). A similar recent study based on 92 honeybee samples reported only four mtDNA haplotypes in Algeria (A1, A2, A8 and A9), with no observation of any imported haplotypes 
[46]. The detection of imported haplotypes, and the higher number of identified haplotypes in our study compared to previous studies, might be due to our bigger sample size and/or the increase of commercial beekeeping activity during the last few years, especially in northern Algeria.

On the other hand, haplotypes A1, A8 and A9 occurred in high frequencies and seemed to be the characteristic haplotypes of North African honeybee populations (Figure 3 and Table 2). These results concur with those obtained in Morocco, where A. m. intermissa and/or A. m.sahariensis have also spread $[9,35,37]$. These African haplotypes have also been recorded in Algerian honeybee populations [46]. Haplotypes A2 and A13 are particularly interesting; they were identified only in Naama (AinSefra), a south Saharan region close to Morocco to which A. m.sahariensis is expected to have spread [2], Figures 3. The same AinSefra samples were analyzed using 14 microsatellite loci [51], and their genomic DNA revealed a clear genetic distinction from A. m.intermissa [51]. Hence, the Naama (AinSefra) honeybee population seems to be genetically closer to the southern African populations. The high frequencies and combination of the two haplotypes (A2 and A13) unique to this population (Figure 3) could provide a particularly interesting way to predict the expected spread of A. $m$. sahariensis' range into this area $[38,39,40]$. However, assigning the A9 haplotype to A. $m$. sahariensis as proposed by Chahbar et al. [46] might not be appropriate, especially given that A9 was recorded in our study in almost all northern Algerian regions, and in Spain [35], where A. m. sahariensis does not occur (Figure 3). At this point, it is difficult to conclude whether the microsatellite distinction of the Naama population and its high frequency of haplotypes A2 and A13 could characterize A. m.sahariensis in its native area of repartition, because this subspecies is poorly documented and because A2 and A13 have also been reported in other locations $[13,35,36,50]$.

Northern Algerian populations had higher genetic diversity than those located in the southern regions. The highest diversity was recorded in the Algiers and Mostaganem populations (0.758), whereas the lowest diversity was seen in the southern populations of Ghardaia and Biskra (0 and 0.221, respectively, Table 2 and Figure 1).

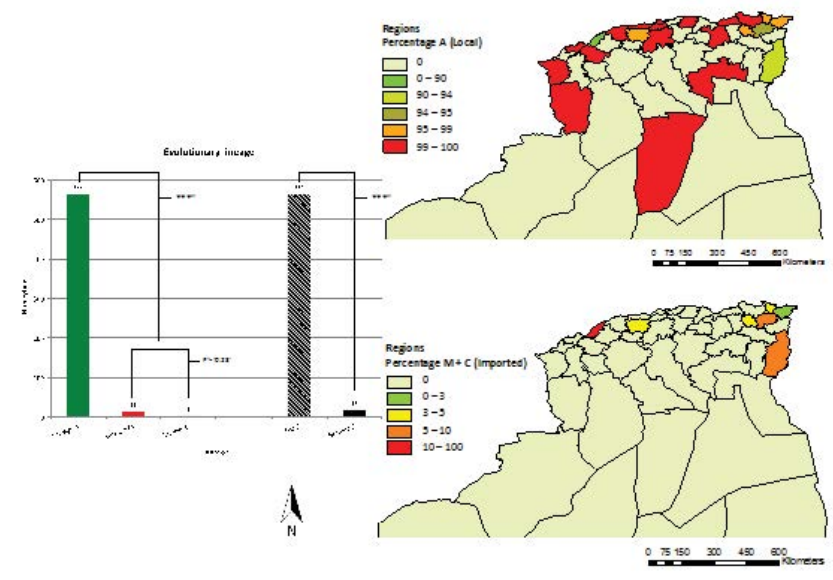

Figure 2. ArcGIS maps of the percentage of mtDNA haplotypes detected in the 22 studied regions of Algeria, revealing two significantly distinct groups: local haplotype $\mathrm{A}$, and imported haplotypes $\mathrm{M}$ and $\mathrm{C}\left({ }^{* * *}\right.$ means $P<0.001$ in paired t-test).

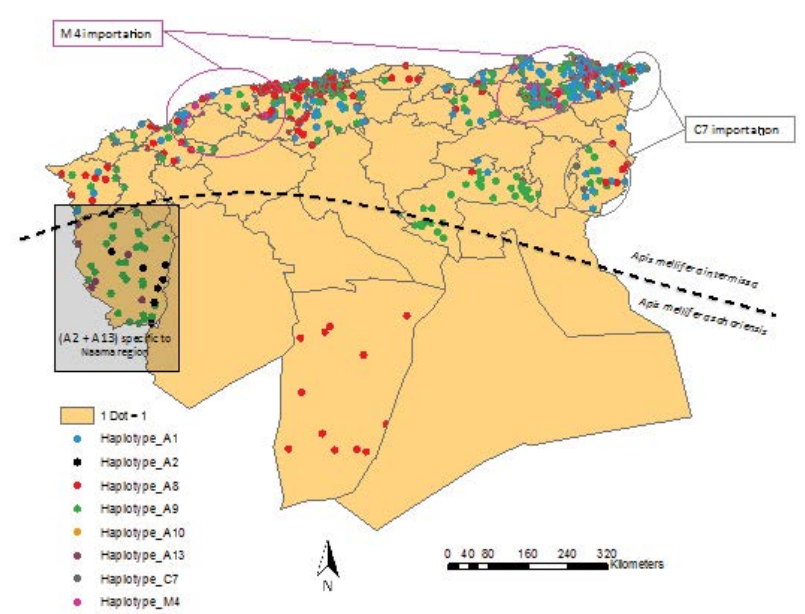

Figure 3: Overview of an ArcGIS dot representation of all mtDNA haplotypes recorded in each of the 22 Algerian populations that were studied. The two imported haplotypes (C7 and M4) were identified in the east and north of the country, respectively. However, haplotypes A2 and A13 were recorded exclusively in Naama (Ain Sefra). Each dot represents one typed honeybee colony. Overall in the dataset, the most dominant haplotypes were A9 (green), A1 (blue) and A8 (red). Geographical delimitation of the subspecies A. m. intermissa and A. m. sahariensis was based on Haccour 1960; Ruttner et al. 1978; Adam 1983; and Ruttner 1988.

This is certainly due to the greater amount of beekeeping activity and transhumance that occurs in the northern regions. Franck et al. [55] obtained similar results, documenting genetic diversity of 0.249 for African honeybee populations from Guinea (Nimba) and 0.567 for a northern population from Morocco (El-Hoceima).

From a conservation point of view, we believe that the punctual introgression identified in Algeria is due to human importation of bees rather than gene flow from Europe, as only African haplotypes were found in Morocco; geographically speaking, that area is more susceptible to face gene flow from Europe than is Algeria [35,37]. A previous similar study reported no foreign honeybee introgression to Algerian populations [46]. Yet now, only a few years later, our data indicate a $3.1 \%$ rate of introgression to the local populations. This increase in foreign honeybee importation should be taken seriously, as it highlights the need for efficient $A$. $m$. intermissa conservation policies across the Algerian territory.

\section{Conclusion}

Our results demonstrated that Algerian honeybee populations belong to the African lineage $\mathrm{A}$ and contained six different mtDNA haplotypes (A1, A2, A8, A9, A10, A13). For the first time, weak introgressions among these populations were recorded, due mainly to the importation of foreign honeybees from the $\mathrm{C}$ and $\mathrm{M}$ lineages. At its current levelof $3.1 \%$, this phenomenon of importation is causing no direct impact on the genetic diversity of local honeybees. Haplotype A9 was recorded in almost all regions studied and hence it is not a useful subspecies-specific marker for A. m. sahariensis, as described in previous studies. The northern Algerian populations showed higher haplotype diversity than those located in the south. Overall, The local Algerian populations of A. mellifera intermissa and/or A. mellifera sahariensis seem to be persisting over a large area of Algeria, with a presence of $96.9 \%$ in the studied regions. 
Citation:Achou M, Loucif-Ayad W, Legout H, Hmidan H, Alburaki M, et al.(2015) An Insightful Molecular Analysis Reveals Foreign Honeybees Among Algerian Honeybee Populations (Apis mellifera L.). J Data Mining Genomics Proteomics 6: 166. doi:10.4172/2153-0602.1000166

\begin{tabular}{|c|c|c|c|c|c|c|c|c|c|c|c|}
\hline \multirow{2}{*}{ Populations } & \multicolumn{8}{|c|}{ Haplotype } & \multirow{3}{*}{ Haplotype diversity \% } & \multirow{3}{*}{ Haplotype introgression \% } & \multirow{3}{*}{ Total } \\
\hline & \multirow{2}{*}{$\begin{array}{c}\mathrm{A1} \\
\mathrm{P}_{0} \mathrm{Q}\end{array}$} & \multirow{2}{*}{$\begin{array}{c}\mathrm{A} 2 \\
\mathrm{P}_{0} \mathrm{Q}\end{array}$} & \multirow{2}{*}{$\begin{array}{c}\mathbf{A 8} \\
\mathrm{P}_{0} \mathrm{Q}\end{array}$} & \multirow{2}{*}{$\begin{array}{c}A 9 \\
P_{0} Q Q\end{array}$} & \multirow{2}{*}{$\begin{array}{c}A 10 \\
P_{0} Q Q Q\end{array}$} & \multirow{2}{*}{$\begin{array}{c}A 13 \\
P_{0} Q Q\end{array}$} & \multirow{2}{*}{$\begin{array}{c}\text { M4 } \\
P Q Q\end{array}$} & \multirow{2}{*}{$\begin{array}{l}\text { C7 } \\
Q\end{array}$} & & & \\
\hline mtDNA COI-COII length & & & & & & & & & & & \\
\hline 1. Ain Defla & 8 & - & 9 & 6 & - & - & 1 & - & 0.714 & 0.24 & 24 \\
\hline 2. Algiers & 4 & - & 4 & 5 & 1 & - & - & - & 0.758 & 0 & 14 \\
\hline 3. Annaba & 20 & - & 14 & 10 & - & - & 2 & - & 0.684 & 4.3 & 46 \\
\hline 4. Biskra & 2 & - & 2 & 30 & - & - & - & - & 0.221 & 0 & 34 \\
\hline 5. Blida & 4 & - & 30 & 22 & - & - & - & - & 0.564 & 0 & 56 \\
\hline 6. Chlef & 2 & - & 3 & 3 & - & - & - & - & 0.750 & 0 & 8 \\
\hline 7. Constantine & 22 & - & 12 & 24 & - & - & 3 & - & 0.685 & 4.9 & 61 \\
\hline 8. El Tarf & 26 & - & 8 & 6 & - & - & - & 1 & 0.551 & 2.4 & 41 \\
\hline 9. Ghardaia & - & - & 12 & - & - & - & - & - & 0 & 0 & 12 \\
\hline 10. Guelma & 21 & - & 3 & 9 & - & - & 2 & - & 0.580 & 5.7 & 35 \\
\hline 11. Jijel & 7 & - & 2 & 2 & - & - & - & - & 0.582 & 0 & 11 \\
\hline 12. Mascara & 3 & - & 6 & 7 & - & - & - & - & 0.675 & 0 & 16 \\
\hline 13. Medea & 14 & - & 11 & 12 & - & - & - & - & 0.682 & 0 & 37 \\
\hline 14. Mostaganem & 5 & - & 3 & 3 & - & - & 7 & - & 0.758 & 38.8 & 18 \\
\hline 15. Naama & - & 8 & - & 30 & - & 6 & - & - & 0.494 & 0 & 44 \\
\hline 16. Oran & 3 & - & 2 & 3 & - & - & - & - & 0.750 & 0 & 8 \\
\hline 17. Setif & 4 & - & 3 & 9 & - & - & - & - & 0.625 & 0 & 16 \\
\hline 18. Skikda & 11 & - & 1 & 6 & - & - & - & - & 0.542 & 0 & 18 \\
\hline 19. Tebessa & 8 & - & 5 & 7 & - & - & - & 2 & 0.740 & 9.1 & 22 \\
\hline 20. Tipaza & 4 & - & 31 & 5 & - & - & - & - & 0.383 & 0 & 40 \\
\hline 21. Tizi Ouzou & - & - & 4 & 1 & - & - & - & - & 0.400 & 0 & 5 \\
\hline 22. Tlemcen & 3 & - & 7 & 6 & - & - & - & - & 0.675 & 0 & 16 \\
\hline Total & 171 & 8 & 172 & 206 & 1 & 6 & 15 & 3 & 0.701 & 3.1 & 582 \\
\hline$\%$ & 29.38 & 1.38 & 29.55 & 35.39 & 0.17 & 1.03 & 2.58 & 0.52 & & & 100 \\
\hline
\end{tabular}

Table 2. Haplotypes present and haplotype diversity in each population, with haplotype percentage among all Algerian populations, and length of the mtDNA COI-COII intergenic region for each haplotype. (-) indicates absence from the region.

\begin{tabular}{|c|c|c|c|c|c|}
\hline Haplotype comparison & t-value & df & Confidence interval & Mean of the differences \\
\hline M4 vs C7 & 1.226 & 21 & -0.3161 to 1.2252 & 0.4545 \\
\hline A1 vs A2 & 4.215 & 21 & 3.7537 to 11.064 & 7.409 \\
\hline A1 vs A8 & -0.019 & 21 & -4.907 to 4.8162 & -0.23 \\
\hline A1 vs A9 & -0.656 & 21 & -6.634 to 3.452 & -1.590 \\
\hline A8 vs A9 & -0.627 & 21 & -6.668 to 3.577 & -1.5454 \\
\hline Local vs Introgressed & -7.227 & 21 & -31.95 to -17.677 & 0.984 \\
\hline
\end{tabular}

Table 3. Pairwise t-test comparisons between the most significant haplotypes found in the 22 Algerian honeybee regions. "Local" haplotypes include all A haplotypes (A1, A2, A8, A9, A10, A13) while the "introgressed" haplotypes were only M4 and C.

\section{Acknowledgement}

This work was supported financially by the Algerian Fund for Scientific Research and by the Ministry of Higher Education and Scientific Research of Algeria. We would like to thank Algerian beekeepers for their contribution to sampling. We are especially grateful to M. Hamzaoui, H. Diffalaf and F. Boussouak for their intensive collaboration.

\section{References}

1. Ruttner F, Tassencourt L, Louveaux J (1978) Biometrical-statistical analysis of the geographic variability of Apis mellifera. Apidologie 9: 363-381.

2. Ruttner F (1988) Biogeography and taxonomy of honeybees. Springer-Verlag, Berlin.

3. Ruttner F (1992) Natural history of honeybees. Ehrenwirth, Munich.

4. Smith DR, Brown WM (1988) Polymorphisms in mitochondrial DNA of European and Africanized honeybees (Apis mellifera). Experientia 44: 257-260.

5. Smith DR, Brown WM (1990) Restriction endonuclease cleavage site and length polymorphism in mitochondrial DNA of Apis mellifera mellifera and A. m. carnica (Hymenoptera: Apidea). Ann Entomol Soc Am 83: 81-88.

6. Garnery L, Vautrin D, Cornuet JM, Solignac M (1991) PhylogeneticRelationships in the Genus Apis Inferred from Mitochondrial-DNA Sequence Data. Apidologie 22(1): 87-92.
7. Hall HG, Smith DR (1991) Distinguishing African and European honeybee matrilines using amplified mitochondrial DNA. Proc Natl Acad Sci U S A 88 4548-4552.

8. Garnery L, Cornuet JM, Solignac M (1992) Evolutionary history of the honey bee Apis mellifera inferred from mitochondrial DNA analysis. Mol Ecol 1: 145154

9. Garnery L, Solignac M, Celebrano G, Cornuet JM (1993) A Simple Test Using Restricted Pcr-Amplified Mitochondrial-DNA to Study the Genetic-Structure of Apis mellifera L. Experientia 49(11): 1016-1021.

10. Arias MC, Sheppard WS (1996) Molecular phylogenetics of honey bee subspecies (Apis mellifera L.) inferred from mitochondrial DNA sequence. Mol Phylogenet Evol 5: 557-566.

11. Franck P, Garnery L, Solignac M, Cornuet JM (2000) Molecular confirmation of a fourth lineage in honeybees from the Near East. Apidologie 31(2): 167-180.

12. Kandemir I, Pinto MA, Meixner MD, Sheppard WS (2006) Hinf-I digestion of cytochrome oxidase I region is not a diagnostic test for A. m. lamarckii. Genet Mol Biol 29(4): 747-749.

13. Alburaki M, Moulin S, Legout H, Alburaki A, Garnery L (2011) Mitochondria structure of eastern honeybee populations from Syria, Lebanon and Iraq Apidologie 42(5): 628-641.

14. Alburaki M, Bertrand B, Legout H, Moulin S, Alburaki A, et al. (2013) A fifth major genetic group among honeybees revealed in Syria. BMC Genet 14: 117 
Citation:Achou M, Loucif-Ayad W, Legout H, Hmidan H, Alburaki M, et al.(2015) An Insightful Molecular Analysis Reveals Foreign Honeybees Among Algerian Honeybee Populations (Apis mellifera L.). J Data Mining Genomics Proteomics 6: 166. doi:10.4172/2153-0602.1000166

15. De la Rua P, Galian J, Serrano J, Moritz RFA (2003) Genetic structure of Balearic honeybee populations based on microsatellite polymorphism. Genetics Selection Evolution 35: 339-350.

16. De la Rua P, Hernandez-Garcia R, Jimenez Y, Galian J, Serrano J (2005) Biodiversity of Apis mellifera iberica (Hymenoptera : Apidae) from northeastern Spain assessed by mitochondrial analysis. Insect Syst Evol 36: 21-28.

17. De la Rua P, Jaffé R, Dall'Olio R, Munoz I., Serrano J (2009) Biodiversity, conservation and current threats to European honeybees. Apidologie 40: 263284.

18. Rortais A, Arnold G, Alburaki M, Legout H, Garnery L (2010) Review of the Dral COI-COll test for the conservation of the black honeybee (Apis mellifera mellifera). Conserv Genet Resour 3: 383-391.

19. Bertrand B, Alburaki M, Legout H, Moulin S, Mougel F, et al. (2014) MtDNA COI-COIl marker and Drone Congregation Area: An efficient method to establish and monitor honeybee (Apis mellifera L.) conservation centers. Mo Ecol Resour [Epub ahead of print].

20. Wallberg A, Han F, Wellhagen G, Dahle B, Kawata M, et al. (2014) A worldwide survey of genome sequence variation provides insight into the evolutionary history of the honeybee Apis mellifera. Nat Genet 46: 1081-1088.

21. Meusel MS, Moritz RF (1993) Transfer of paternal mitochondrial DNA during fertilization of honeybee (Apis mellifera L.) eggs. Curr Genet 24: 539-543.

22. de la Rúa P, Serrano J, Galián J (1998) Mitochondrial DNA variability in the Canary Islands honeybees (Apis mellifera L.). Mol Ecol 7: 1543-1547.

23. Palmer MR, Smith DR, KaftanoÄŸlu O (2000) Turkish honeybees: genetic variation and evidence for a fourth lineage of Apis mellifera mtDNA. J Hered 91: 42-46.

24. De la Rúa P, Galián J, Serrano J, Moritz RF (2001) Genetic structure and distinctness of Apis mellifera L. populations from the Canary Islands. Mol Ecol 10: $1733-1742$

25. Munoz I, Stevanovic J, Stanimirovic Z, De la Rua P (2012) Genetic variation of Apis mellifera from Serbia inferred from mitochondrial analysis. J Apic Sci 56: 59-69.

26. Cornuet JM, Garnery L (1991) Mitochondrial DNA variability in honeybees and its phylogeographic implications. Apidologie 22: 627-642.

27. Cornuet JM, Garnery L, Solignac M (1991) Putative origin and function of the intergenic region between $\mathrm{COI}$ and $\mathrm{CO}$ II of Apis mellifera L. mitochondrial DNA. Genetics 128: 393-403

28. Estoup A, Garnery L, Solignac M, Cornuet JM (1995) Microsatellite variation in honey bee (Apis mellifera L.) populations: hierarchical genetic structure and test of the infinite allele and stepwise mutation models. Genetics 140: 679-695.

29. Sheppard WS, Arias MC, Grech A, Meixner MD (1997) Apis mellifera ruttneri, a new honey bee subspecies from Malta. Apidologie 28: 287-293.

30. Sheppard WS, Meixner MD (2003) Apis mellifera pomonella, a new honey bee subspecies from Central Asia. Apidologie 34: 367-376.

31. Solignac M, Vautrin D, Loiseau A, Mougel F, Baudry E, et al. (2003) Five hundred and fifty microsatellite markers for the study of the honeybee (Apis mellifera L.) genome. Mol Ecol Notes 3: 307-311.

32. Han F, Wallberg A, Webster MT (2012) From where did the Western honeybee (Apis mellifera) originate? Ecol Evol 2: 1949-1957.

33. Meixner M, Pinto M, Bouga M, Kryger P, Ivanova E, et al. (2013) Standard methods for characterizing subspecies and ecotypes of Apis mellifera. Journal of Apicultural Research 52:1-27.

34. Papachristoforou A, Rortais A, Bouga M, Arnold G, Garnery L (2013) Genetic characterization of the Cyprian honey bee (Apis mellifera cypria) based on microsatellites and mitochondrial DNA polymorphisms. Journal of Apicultural Science 2(57): 127-134.

35. Garnery L, Mosshine EH, Oldroyd BP, Cornuet JM (1995) Mitochondrial-DNA Variation in Moroccan and Spanish Honey bee Populations. Molecular ecology 4: 465-471.

36. Smith DR, Palopoli MF, Taylor BR, Garnery L, Cornuet JM, et al. (1991) Geographical overlap of two mitochondrial genomes in Spanish honeybees (Apis mellifera iberica). J Hered 82: 96-100.
37. Franck P, Garnery L, Loiseau A, Oldroyd BP, Hepburn HR, et al. (2001) Genetic diversity of the honeybee in Africa: microsatellite and mitochondrial data. Heredity (Edinb) 86: 420-430.

38. De la Rua P, Radloff S, Hepburn R, Serrano J (2007) Do molecular markers support morphometric and pheromone analyses. A preliminary case study in Apis mellifera populations of Morocco. Arch Zootec 56: 33-42.

39. Baldensperger PJ (1924) North African bees, II. Bee World 5: 189-190.

40. Haccour P (1960) Recherche sur la race d'abeille saharienne au Maroc. Bulletin de la Société des Sciences naturelles et physiques du Maroc 6: 96-98.

41. Adam B (1983) In Search of the Best Strains of Honey bee. Northern Bee Books. West Yorkshire, UK

42. Grissa K, Cornuet JM, Msadda K, Fresney J (1990) Etude biométrique des populations d'abeilles Tunisienne. Apidologie 21: 303-310.

43. Cornuet JM, Daoudi A, Mohssine EH, Fresney J (1988) Etude biométrique des populations d'abeilles Marocaines. Apidologie 19: 355-366.

44. Loucif-Ayad W, Tahar A (2001) Etude biométrique de populations d'abeilles Algériennes: Apis mellifera intermissa. Revue des Sciences et Technologie " Synthèse », numéro spécial, Biologie Animale, $n^{\circ} 9$, Université d'Annaba.

45. Barour C, Tahar A, Radloff S, Hepburn H (2005) Multivariate analysis of honey bees, Apis mellifera Linnaeus (Hymenoptera: Apidae) of the northeastern and southern regions of Algeria. African Entomology 13: 17-23.

46. Chahbar N, Muñoz I, Dall'Olio R, De la Rua P, Serrano J, et al. (2012) Population structure of North African honey bees is influenced by both biological and anthropogenic Factors. J Insect Conserv 17: 385-392.

47. Kocher TD, Thomas WK, Meyer A, Edwards SV, Pääbo S, et al. (1989) Dynamics of mitochondrial DNA evolution in animals: amplification and sequencing with conserved primers. Proc Natl Acad Sci U S A 86: 6196-6200.

48. Nei M, Tajima $F$ (1981) DNA polymorphism detectable by restriction endonucleases. Genetics 97: 145-163.

49. Dean CB, Nielsen JD (2007) Generalized linear mixed models: a review and some extensions. Lifetime Data Anal 13: 497-512.

50. Miguel I, Iriondo M, Garnery L, Sheppard WS, Estonba A (2007) Gene flow within the $M$ evolutionary lineage of Apis mellifera: role of the Pyrenees, isolation by distance and post-glacial re-colonization routes in the western Europe. Apidologie 38: 141-155.

51. Loucif-Ayad W, Achou M, Legout H, Alburaki M, Garnery L (2014) Genetic assessment of Algerian honeybee populations by microsatellite markers. Apidologie.

52. Chouchène $M$ (2010) Contribution in the study of biodiversity of Apoidea in Tunisia: Morphometric, molecular and eco-physiologic study of Tunisian bee: Apis mellifera intermissa (Hymenoptera: Apidae). Tunisian Journal of Plant Protection 5(1): 205

53. Garnery L, Franck P, Baudry E, Vautrin D, Cornuet JM, et al. (1998a) Genetic diversity of the west European honey bee (Apis mellifera mellifera and A. m. iberica). I. Mitochondrial DNA. Genetics Selection Evolution 30: S31-S47.

54. Perrier C, Strange J, Langella O, Shappard SW, Garnery L (2003) Diversité génétique, introgressions mitocondriales et nucléaires dans une population d'abeilles des Landes de Gascogne. Actes Bureau Resources Génétiques 4 : 79-100.

55. Franck P, Garnery L, Solignac M, Cornuet JM (1998) The origin of west European subspecies of honeybees (Apis mellifera): New insights from microsatellite and mitochondrial data. Evolution 52: 1119-1134. 